\title{
Active compounds in EAhy 926 endothelial cells, investigating cashew extract and molecules as natural health product approach to reducing the formation of advanced glycation endproducts
}

\begin{abstract}
Cashew, Anacardium occidentale Linn of the family Anacardiaceae, has been documented as traditional plant treatment for diabetes and hypertension. In our previous studies using A. occidentale leaf and seed extracts, we demonstrated the effective improvement in renal or testis function and reduced lesions associated with diabetic state in STZ-diabetic rats and stimulating glucose transport in $\mathrm{C} 2 \mathrm{C} 12$ muscle cells. ${ }^{1-3}$ We then wondered what molecular compounds were involved in these potent anti-diabetic activities. In the present study, using antioxidant activity-guided fractionation (DPPH advanced glycation endproducts (AGEs) essays), four extracts (E1 to E4) of $A$. occidentale leaves were studied for possible antioxidant capacities and vascular activity. We also compared the protective effects of cashew leaf extracts against high glucose mediated toxicity in cultured bovine aortic endothelial cells (EAhy 926 cells). Total antioxidant activity of the extracts of $A$. occidentale and identified compounds was determined using DPPH free radical scavenging assay. Two extracts of cashew's leaves, E3 and E4, were found to possess significant DPPH radical-scavenging activity with equivalent trolox values of $218 \pm 8$ and $760 \pm 3 \mathrm{mg}$ trolox/g dried extract, respectively. The order of the radical scavenging potency is $\mathrm{E} 4>\mathrm{E} 3>\mathrm{E} 2>\mathrm{E} 1$.
\end{abstract}

In vitro AGEs generation after $24 \mathrm{~h}$ revealed that $\mathrm{E} 3$ had the strongest inhibitory activity against AGEs formation and its $\mathrm{IC}_{50}$ value was $0.070 \mathrm{mg} / \mathrm{ml}$ compared to that of aminoguanidine as standard $(0.826 \mathrm{mg} / \mathrm{ml})$. A significant $(p<0.05)$ increase in fluorescence of AGEs in $25.0 \mathrm{mM}$ glucose $(\mathrm{HG})$ was partially corrected by E3, E4 and agathisflavone (AF) $(p<0.05)$ vs. $25 \mathrm{mM}$ glucose alone. Additionally, cotreatment with E3, E4 or AF significantly attenuated HG induced EAhy as judged by overexpression of Mn-SOD and NF-kB.

These results suggest that $A$. occidentale $\mathrm{MetOH}$ extracts together with its principal compound, identified as agathisflavone reduces high glucose-induced toxicity by attenuating AGEs, MnSOD, NF-kB generation in endothelial cells, and therefore may be of significant therapeutic benefits against oxidative stress in diabetic complications and hypertension.

Keywords: Anacardium occidentale, leaves extracts, hyperglycaemic conditions, glycation, endothelial cells, oxidative stress

\section{Introduction}

Diabetes is the most common non-communicable diseases worldwide. ${ }^{4}$ It has become one of the leading causes of morbidity and mortality in developed countries, and the management of hyperglycaemia remains a major therapeutic concern. In the fourth edition of International Diabetes Federation Atlas, ${ }^{4}$ it has been stated that the estimated diabetes prevalence for 2010 has risen to 280 million, representing $6.6 \%$ of the world's population. Although diagnosed on the basis of hyperglycaemia, diabetes mellitus is associated with broad metabolic abnormalities that contribute to microvascular and macrovascular complications. ${ }^{5}$ Studies based on cultured endothelial cells have clearly shown that endothelial cell growth is inhibited by hyperglycemia. ${ }^{6}$ The mechanism of glucose inhibiting endothelial cell growth has not been clearly defined but may be related to generation of Reactive Oxygen Species (ROS). Previous studies have shown
Volume 12 Issue I - 2019

\author{
Leonard Tedong,' Desire Paul D Dzeufiet, ${ }^{2}$ \\ Danielle Bilanda, ${ }^{2}$ SD Sockeng FM \\ Kanmangne,' PD Chuisseu,' P Haddad, ${ }^{3}$ \\ Andrea Rosanoff, 4,5 \\ 'Department of Physiology, High Institute of Health, University \\ Cameroon, Cameroon \\ ${ }^{2}$ Department of Animal Biology and Physiology, University of \\ Yaounde, Cameroon \\ ${ }^{3}$ Department of Pharmacology, University of Montreal, Montreal, \\ Canada \\ ${ }^{4}$ Department of Animal Biology and Physiology, University of \\ Ngaoundere, Cameroon \\ ${ }^{5}$ Center for Magnesium Education \& Research Pahoa, USA
}

\begin{abstract}
Correspondence: Leonard Tedong, Department of Physiology, High Institute of Health, University “des Montagnes”, Bangante, Cameroon, Tel +237 758976 09, +237 69। I44 920, Email Itedong@yahoo.fr
\end{abstract}

Received: December 28, 2018 | Published: February 25, 2019 
but medicines that completely ameliorate diabetes mellitus have not yet been founded. The specie Anacardium occidentale Linn (A. occidentale) commonly known as cashew tree, belongs to the family Anacardiaceae which includes the mango, Mangifera indica L., and the Spondias genus. Cashew plant is cultivated for its edible fruit and nut in addition to its traditionally medicinal values. The economic importance of this special tree is such that it is now widely distributed throughout the tropics, particularly in many parts of Africa and Asia. Cashew seeds are rich in flavonoids and monounsaturated fatty acids such as linoleic acid (Omega-3) which is associated with a lower prevalence of coronary artery disease. ${ }^{10}$ It is also reported that the cashew nut extract and some isolated compounds have anti-oxidant properties. ${ }^{11}$ The cashew tree also produces a pseudo-fruit called the cashew apple that is commonly consumed in the northern Cameroon. Studies on the biological activities of fresh cashew apple juice (CAJ) have shown that not only does it exhibit antibacterial and antitumor activities; it also has antioxidant and antimutagenic properties. ${ }^{12}$ Previously, studies have demonstrated anti-diabetic effects of $A$. occidentale leaf, stem-bark and seed extracts. ${ }^{1,13,14}$ Other studies in our research team also reported the ability of extracts of $A$. occidentale leaves to provide pancreatic protection against streptozotocin-induced diabetes in rats. ${ }^{13}$ More recently, we demonstrated a stimulating effect of cashew seeds extract on glucose transport in $\mathrm{C} 2 \mathrm{C} 12$ muscle cells. ${ }^{3}$

To date, there have been no studies of the effect of cashew's leaf extracts and related compounds on protein glycation inhibitory activity and oxidative stress induced by hyperglycemia. Therefore, the aim of the present study was: (1) to search for potential antioxidant and anti-AGEs effects of $A$. occidentale's leaf extracts for application in the treatment of diabetes and hypertension (2) to determine whether treatment with $A$. occidentale's extracts may improve high glucoseinduced endothelial dysfunction and if so, to investigate the signalling pathway involved.

\section{Materials and methods}

\section{Reagents}

The human EA.hy 926 endothelial cells lines were purchased from American type culture collection (University of North Carolina, USA). Dulbecco's modified Eagle's medium (DMEM) containing $25 \mathrm{mM}$ (4.5g/l) glucose, Foetal Bovine Serum (FBS), Trypsin EDTA, were obtained from Lonza (Verviers, Belgium). The following chemicals: 4-hydroxy-tempo, L-glucose, DPPH (1, 1-diphenyl-2-picrylhydrazyl) as Nitrate/Nitrite assay kits, superoxide anion assay kits, glutathione assay kits, monoclonal antibody (anti-catalase) were purchased from Sigma Aldrich Co. (St. Louis, MO, USA).

\section{Plant material}

Anacardium occidentale were collected in May 2007 in Garoua (Northen Province), Cameroon. The plant samples were identified in the National Herbarium Cameroon (NHC), Obili-Yaounde, Cameroon. A voucher specimen of the collected plant sample was also deposited in the herbarium and given a specimen number 65604/NHC. Leaves were separated and dried under shade for three days. Dried leaf samples were ground into a uniform powder using a blender.

\section{Preparation of extracts}

$880 \mathrm{~g}$ of the dried powdered Cashew tree leaf samples were taken separately in a paper cone and placed into Soxhlet apparatus. Cyclohexane $(4 \mathrm{~L})$, an organic solvent was taken in the round bottom flask attached to the Soxhlet apparatus. A condenser was attached to this set up (with a temperature set in the range of $25-30^{\circ} \mathrm{C}$ ). The whole set up was placed on a heating mantle. Cyclo-hexane gets vaporized and rises up to the condenser where it condenses back into liquid. This process was continued until maximum extraction from the plant by cyclohexane. The same procedure was repeated with three other solvents: dichloromethane (DCM), ethyl acetate EtOAc), and methanol $(\mathrm{MeOH})$. The extracts from each of the above overnight evaporations were stored in vials.

\section{Compound isolation $\&$ identification}

Analytical TLC followed by flash column chromatography of EtOAc and $\mathrm{MeOH}$ extracts was carried out on precut plates (Si gel F 254 from EM science). The structures of compounds were identified and confirmed by their TLC profiles as well as their HPLC and NMR spectra.

\section{In vitro studies}

Free-radical scavenging activity: The potential antioxidant activity of cashew leaf extracts and isolated compounds from E3 and E4 were assessed on the basis of scavenging activity of stable DPPH (1-phenyl-2-picrylhydrazyl) radical free radical. In its radical form, DPPH has an absorption band at $520 \mathrm{~nm}$ which disappears upon reduction by antiradical compound(s). The reaction mixture $(3.15 \mathrm{~mL})$ contained $3 \mathrm{~mL}$ of daily prepared DPPH solution $(0.025 \mathrm{~g} / \mathrm{L})$ and different concentrations of cyclo-hexane, DCM , EtOAc and $\mathrm{MeOH}$ extracts (E1, E2, E3 and E4, respectively) of A. occidentale or tested compounds dissolved in methanol. After 30minutes at room temperature, the absorbance was recorded at $520 \mathrm{~nm}$. The DPPH concentration in the reaction medium was calculated from a calibration curve analysed by linear regression. The percentage of disappeared DPPH was calculated as follows: (1- [DO] test group/ [DO] reference without any antioxidant)x100. A Trolox calibration curve was constructed by measuring the reduction in absorbance of the DPPH solution in the presence of different concentrations of Trolox (0-4001M). The DPPH radical scavenging activity of the extracts was measured using the Trolox standard curve and results were expressed as mg Trolox equivalent (TE) antioxidant capacity per g dried plant sample. Measurements were performed at least in triplicate; means and S.D. were calculated. Romarin and chlorogenic acid were used as positive controls.

Chemical determination of total AGEs by fluorescence measurement: A Maillard fluorescence-based assay was developed and optimized for screening of crude extracts (E1, E2, E3 and E4) and chemical compounds (Agathisflavone) that are able to inhibit the formation of AGEs. The assay involved incubating BSA (10mg/ $\mathrm{mL}$ ) with D-ribose $(0.5 \mathrm{M})$ and the tested compounds (3.10-6 to 3.10$3 \mathrm{M})$ or extracts $(10-6$ to $1 \mathrm{mg} / \mathrm{mL})$ in a phosphate buffer $50 \mathrm{mM} \mathrm{pH}$ 7.4. Solutions were incubated in microplate ( 96 wells) at $37^{\circ} \mathrm{C}$ for 24 hours in a closed system. AGEs fluorescence (excitation: $370 \mathrm{~nm}$; emission: $440 \mathrm{~nm}$ ) was measured using a spectrofluorimeter Infinite M200 (Tecan, Lyon, France). To avoid quenching phenomena, the fluorescence resulting from the incubation in the same conditions of BSA $(10 \mathrm{mg} / \mathrm{mL})$ and the tested compounds or extract $(10-6$ to $1 \mathrm{mg} /$ $\mathrm{mL}$ ) was subtracted for each measure. Negative control, indicated as $100 \%$ inhibition of AGEs formation consisted of wells with only BSA. Positive control, with no inhibition of AGEs formation consisted of wells with BSA and D-ribose. The final volume assay was $100 \mu \mathrm{L}$. The percentage inhibition of AGEs formation was $=[1$-(fluorescence 
of test group/fluorescence of the control group)] x 100\% (Wu and Yen, 2005). The IC50 (defined as concentration of $50 \%$ inhibition AGEs) values for each sample were derived (???). From dose-response curves using Microsoft-Excel computer software. Tests were performed in triplicate.

Cell culture and treatment: Regarding the high antiradical, the anti-glycation and the vasorelaxant activity of $A$. occidentale extracts, we decided to continue our investigation with E3 and E4 on cell culture. EAhy 926 cells were cultured at a density of 1x106 per $75-\mathrm{cm} 2$ flask (Lifes Sciences, Croning, NY, 14831, USA) in DMEM (Dulbecco's modified Eagle's medium: Ham's F-12, 1:1; Lonza) supplemented with $1 \%$ L-glutamine, $1 \%$ non-essential amino acids, $1 \%$ Na-pyruvate, $1 \%$ streptomycin/penicillin (Lonza, Belgium), $1 \%$ hypoxanthine, aminopterin, thymidine (Sigma-Aldrich) and 10\% of heat-inactivated foetal bovine serum (Invitrogen, Cergy Pontoise, France). The culture was maintained at $37^{\circ} \mathrm{C}$ in a humidified incubator gassed with $5 \% \mathrm{CO} 2$.

Protection of EAhy 926 cells from glucose toxicity induced advanced glycosylation end-products (AGEs). After reaching confluence, EA.hy 926 cells were seeded at a density of $1.5 \times 105$ cells/ well in 6-well tissue culture plates (Lifes Sciences, Croning, NY, 14831, USA). To test for cytoprotective activities against glucose toxicity, viability assays were performed on EA.hy 926 cells subjected to chronically elevated glucose in the presence of extracts or vehicle $(0.1 \%$ DMSO). Cells were seeded in $96-$ well plates at a density of $6.25 \times 103$ cells/ well and cultured for $24 \mathrm{~h}$ at $37^{\circ} \mathrm{C}$. Complete medium was then replaced with serum-free medium adjusted to $25 \mathrm{mM}$ glucose (approx. 5-fold greater than normal concentration for this cell line) and supplemented with $0.025 \%$ BSA, with extracts or vehicle (DMSO) for 7days. While these conditions feature a supraphysiological concentration of glucose (the concentrations observed in severe unmanaged diabetes can attain levels 7-fold greater than normal), they are necessary to induce apoptosis in approximately $40 \%$ of the cells over the 4-day experimental duration and to provide adequate experimental resolution. Under this paradigm, toxicity is due to glucose per se and not osmotic stress since the substitution of L-glucose by D-glucose abolishes toxicity.

Groups of cells were formed each one receiving the following fresh media every 48h: normal glucose medium (NG; 5mmol/L D-glucose), high glucose medium (HG; $25 \mathrm{mmol} / \mathrm{L}$ D-glucose), or hyperosmotic control medium $(5.5 \mathrm{mmol} / \mathrm{L}$ D-glucose plus $19.5 \mathrm{mmol} / \mathrm{L}$ L-glucose) for up to 7 days. In experiments, crude extract of $A$. occidentale leaves or isolated compounds solution, $100 \mathrm{mg} / \mathrm{ml}$ and $100 \mathrm{mmol} / \mathrm{L}$ respectively were prepared in $100 \%$ DMSO or water and stored at $-20^{\circ} \mathrm{C}$. Each solution was then diluted and added as supplemented to cell culture media containing high glucose. The final DMSO concentration in the medium was $0.1 \%$. Experimental groups of cells were formed each one receiving EtOAc extract or $\mathrm{MeOH}$ extract of cashew leaves at doses of $7,12.5$ and $25 \mu \mathrm{g} / \mathrm{ml}$ wile isolated compounds groups received $5,10 \mu \mathrm{mol} / 1$ and $20 \mu \mathrm{mol} / 1$ for 7 days. Control assays were performed without extracts, but equivalent volume of DMSO was added. When needed, pharmacological chemical, tempol $(10 \mathrm{mmol} / \mathrm{l})$ were incubated in parallel group and used as positive control.

Effect of $\boldsymbol{A}$. occidentale leaf extracts on cell viability: At the end of experiment, the cells were harvested after trypsinized with $0.05 \%$ trypsin $(\mathrm{ml} /$ well $)$ for $5 \mathrm{~min}$. DMEM $(2 \mathrm{ml} /$ well $)$ was added to neutralise the trypsin. The cells suspensions $(20 \mu l)$ were mixed with $0.2 \%$ trypan blue $(20 \mu \mathrm{l})$ and counted using a malassez chamber.
In another set of experiment, cell viability was determined using a 3-[4,5-dimethylthiazol-2-yl] K2,5-diphenyl tetrazolium bromide (MTT), quantitative colorimetric method as previously described. ${ }^{15}$ The MTT assay was performed in triplicate for each drug used.

Western blotting: To investigate a possible antioxidant mechanism of cashew leaves's action, NF-kB, catalase and MnSOD expression was evaluated by Western blot analysis as we previously described.

\section{Statistical analysis}

All values are expressed as mean $\pm \mathrm{SD}$. Statistical significance was determined using analysis of variance (ANOVA) followed by Tukey's test. $\mathrm{P}<0.05$ was considered statistically significant.

\section{Results}

Chemical characterization and Identification of a flavonoid from EtOAc and $\mathrm{MeOH}$ extracts of cashew leaves

For leaves of $A$. occidentale extracted with EtOAc and $\mathrm{MeOH}$, the HPLC "fingerprint" of the extracts showed major peaks at retention times (min) of 4.84, 21.41 and 27.90 at wavelength of $254 \mathrm{~nm}$ (Figure 1A). Purification was achieved by a combination of polyamide and sephadex LH-20 columns. Figure 1B shows, as an example, the HPLC-UV chromatogram of a purified flavonoid extract obtained from the EtOAc extract of $A$. occidentale. Phytochemical and semipreparative studies resulted in the isolation of two compounds: Agathisflavone, determined by UV, MS, and NMR spectra (Figure 1B \& Figure 2), plus a second compound we named Q13 that was not completely identified (data not shown).

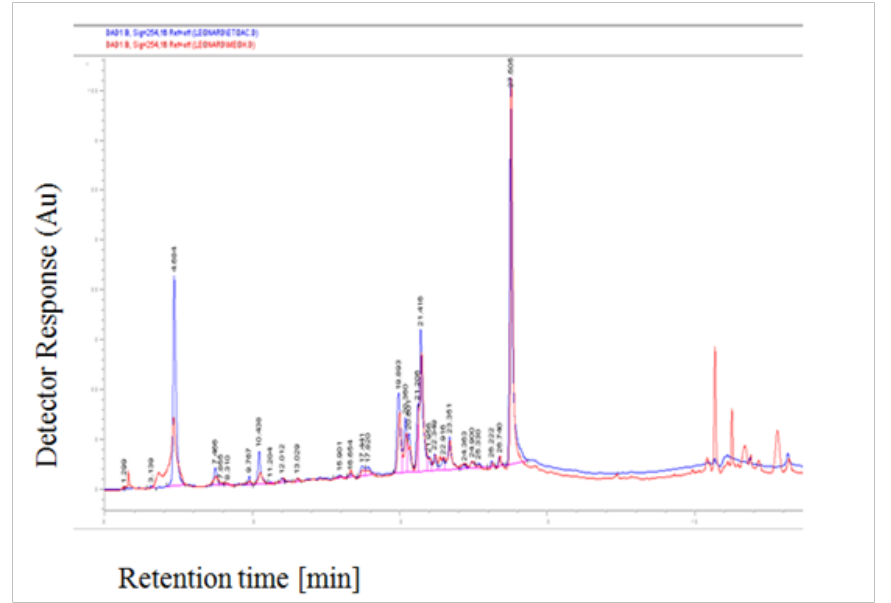

Figure IA HPLC chromatogram of cashew leaves' EtOAc (Blue line) and $\mathrm{MeOH}$ extracts (Red line) (from Cameroon). Peak 30,Agathisflavone.

\section{Chemical assays}

Antioxidant activity of $A$. occidentale extracts using scavenging of 1,1-diphenyl-2-picrylhydrazyl (DPPH)

The radical scavenging activities of the extracts of $A$. occidentale were estimated using the Trolox standard curve and results were expressed as milligram Trolox equivalent (TE) antioxidant capacity per $g$ dried plant sample. Except cyclohexane extract, all other extracts show free radical scavenging activity at different potencies. The highest scavenging activity of DPPH was observed for the $\mathrm{MeOH}$ extract, with $760 \pm 32 \mathrm{mg}$ trolox equivalent/g dried extract followed by the EtOAc and DCM extracts with values of $217 \pm 8$ and $24 \pm 3 \mathrm{mg}$ 
Trolox equivalent/g dried extract, respectively, compared to that of romarin, $64 \pm 3 \mathrm{mg}$ TE/g dried extract (Table 1).

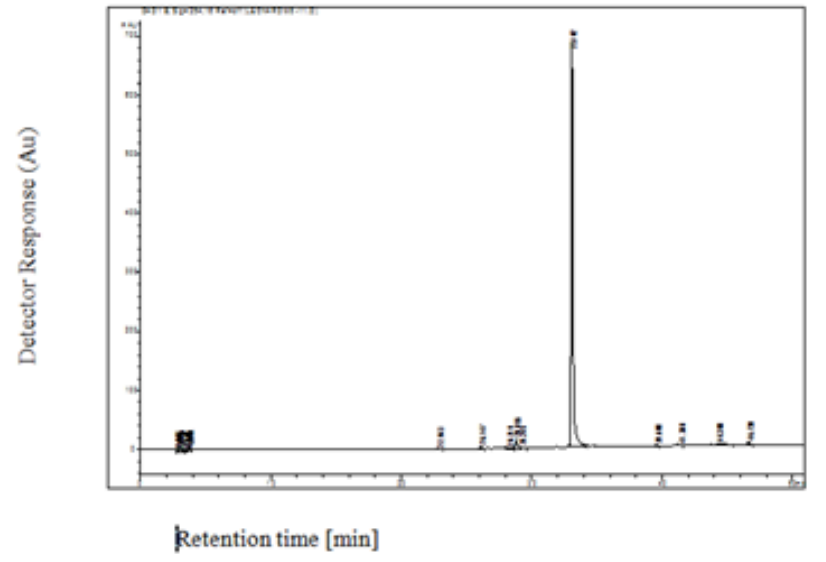

Figure IB HPLC chromatogram: UV absorption spectra of Agathisflavone.<smiles>O=c1cc(-c2ccc(O)cc2)oc2c(-c3c(O)cc(O)c4c(=O)cc(-c5ccc(O)cc5)oc34)c(O)cc(O)c12</smiles>

Figure 2 Structure of biflavonoid, Agathisflavone major compound isolated from EtOAc extract leaves of $A$. occidentale.

Table I Inhibiting effect of different extracts of A. occidentale leaves and isolated compounds on free radical generation in vitro, compared to Romarin and chlorogenic acid

\begin{tabular}{|l|l|l|l|}
\hline $\begin{array}{l}\text { A occidentle leaves } \\
\text { extracts } 0.1 \mathrm{~g} / \mathrm{L}\end{array}$ & $\begin{array}{l}\mathrm{mg} \text { Trolox } \\
\text { equivalent/g } \\
\text { dried extract }\end{array}$ & $\begin{array}{l}\text { Compounds } \\
50 \mu \mathrm{M}\end{array}$ & $\mathrm{TE} / \mu \mathrm{g}$ \\
\hline Cyclohexane (E1) & $12 \pm 1$ & Not detected & - \\
\hline Dichloromethane (E2) & $24 \pm 3$ & Not detected & - \\
\hline Ethyl acetate (E3) & $217 \pm 8$ & Agathisflavone & $16 \pm 1$ \\
\hline Methanol (E4) & $760 \pm 3$ & $\begin{array}{l}\text { Q13 (from E3 or } \\
\text { E4) }\end{array}$ & $642 \pm 3$ \\
\hline Romarin & $64 \pm 7$ & Chlorogenic acid & $53 \pm 2$ \\
\hline
\end{tabular}

Inhibitory effect of A. occidentale extracts and isolated compounds on chemical AGEs formation

The formation of total AGEs was assessed by monitoring the production of fluorescent products at excitation and emission maxima of $440 \mathrm{~nm}$, as previously explained. Figure $3 \mathrm{~A} \& 3 \mathrm{~B}$ shows the effects of $A$. occidentale leaf extracts and major identified compound
(Agathisflavone) on ribose-BSA AGEs formation during 24h of BSA incubation at $37^{\circ} \mathrm{C}$. The fluorescence intensity of this glycophore which is characteristic of AGEs, was highly increased through incubation of BSA during $24 \mathrm{~h}$. The results showed that $A$. occidentale leaf extracts inhibited the AGEs formation in the following order: EtOAc $>\mathrm{MeOH}>\mathrm{DCM}>$ Cyclohexane (Figure 3A). As it is evident in the same figure, EtOAc extract at different concentrations (10-100 $\mathrm{mg} / \mathrm{ml}$ ) has significantly quenched the fluorescence and the result is more pronounced than that of aminoguanidine, the positive control compound known as an inhibitor of glycation process (91\% vs $80 \%$ at a concentration of $3 \mathrm{mg} / \mathrm{ml}$ ). The higher inhibitory effect of EtOAc extract is also evident with the IC50 (defined as the concentration of extract or test compound required to produced $50 \%$ inhibition) value which is higher than that of Cyclohexane, DCM and $\mathrm{MeOH}$ or aminoguanidine $(0.070 \mathrm{vs} 0.374,0.221,0.153$ and $0.826 \mathrm{mg} / \mathrm{ml})$, Table 2. The effect of agathisflavone shown in Figure 3B demonstrated that this major compound isolated from EtOAc and $\mathrm{MeOH}$ extracts inhibited the fluorescence intensity induced by glycation process. Agathisflavone significantly suppressed fluorescence intensity more than did aminoguanidine in a dose-dependent manner; agathisflavone's IC50 was $9.5 \times 10-2 \mu \mathrm{mol} / 1$ versus $516.9 \times 10-2 \mu \mathrm{mol} / 1$ for aminoguanidine, the positive control (Table 2).

Table $\mathbf{2}$ The $\mathrm{IC}_{50}$ of $A$. occidentale leaves extracts and isolated compound on AGEs formation

\begin{tabular}{|l|l|l|l|}
\hline Extracts & $\begin{array}{l}\text { IC50 } \\
(\mathrm{mg} / \mathrm{ml})\end{array}$ & Compounds & $\begin{array}{l}\text { IC50 x 10-2 } \\
(\mu \mathrm{mol} / \mathrm{l})\end{array}$ \\
\hline Cyclohexane & 0.374 & - & - \\
\hline DCM & 0.221 & - & - \\
\hline EtOAc & 0.07 & Agathisflavone & 5.2 \\
\hline MeOH & 0.153 & & - \\
\hline Aminoguanidine & 0.826 & Aminoguanidine & 0.096 \\
\hline
\end{tabular}

\section{In vitro bioassays}

Anacardium occidentale leaf extracts or an isolated biflavonoid (Agathisflavone) protection against glucose induced advanced glycosylation end-products (AGEs) in EAhy 926 cells.

EA.hy 926 endothelial cells were cultured for 7 days in experimental media, after which spontaneous fluorescence was measured as a nonspecific marker of AGEs production. Fluorescence was increased more in $25.0 \mathrm{mM}$ glucose than in $5.5 \mathrm{mM}$ glucose (Figure 4$)(\mathrm{p}<0.05)$. This augmentation was partially corrected by both the EtOAc extract (E3) and the $\mathrm{MeOH}$ extract (E4) as well as agathisflavone (AF) $(\mathrm{p}<0.05)$ vs. $25 \mathrm{mM}$ glucose alone). The fluorescence levels obtained with E3, E4 and Agathisflavone added to $25 \mathrm{mM}$ glucose did not differ significantly between them.

Protection of Anacardium occidentale leafs extracts or an isolated biflavonoid (Agathisflavone) against cell proliferation in EAhy 926 cells.

EtOAc or $\mathrm{MeOH}$ extracts (E3 or E4) to a lesser extent protect against glucose-induced inhibition of cell proliferation (see above and Figure 4). Proliferation of endothelial cells (cell viability) exposed on $25 \mathrm{mmol} / 1$ glucose for 7 days was reduced to $78 \pm 1 \%$ of that in physiological $(5.5 \mathrm{mmol} / 1)$ glucose (Figure 5). In the presence of 7 and $12.5 \mu \mathrm{g} / \mathrm{ml}$ of EtOAc extract of A. occidentale leaves (E3), proliferation of endothelial cells grown in $25 \mathrm{mmol} / 1$ glucose was reduced to $91 \%$ and $93 \%$, respectively, of that in cells grown in 
$5.5 \mathrm{mmol} / 1$ glucose alone. MetOH extract (E4) at the doses of $7 \mu \mathrm{g} / \mathrm{ml}$ and $12.5 \mu \mathrm{g} / \mathrm{ml}$ increased the proliferation of endothelial cells to $84 \%$ and $89 \%$, respectively. Agathisflavone, a major compound isolated from EtOAc $\mathrm{t}$ and $\mathrm{MeOH}$ extracts, was particularly effective in protecting against the anti-proliferative effects of high glucose. In the presence of $5 \mu \mathrm{mol} / 1$ of agathisflavone and $5 \mu \mathrm{mol} / 1$ of tempol (positive control), proliferation of endothelial cells grown in $25 \mathrm{mmol} / 1$ of glucose for 7 days was $93 \pm 5 \%$, of that in cells grown in $5.5 \mathrm{mmol} / 1$ glucose (Figure 6). The proliferation of cells grown in $5.5 \mathrm{mmol} / 1$ of glucose was not different of that of cells grown in $19.5 \mathrm{mmol}$ of L-Glucose and $5.5 \mathrm{mmol} / 1$ of glucose taken as osmotic control (results not shown).

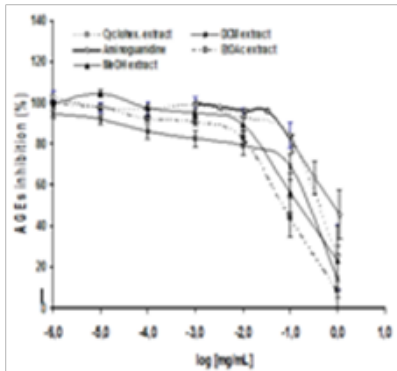

(A)

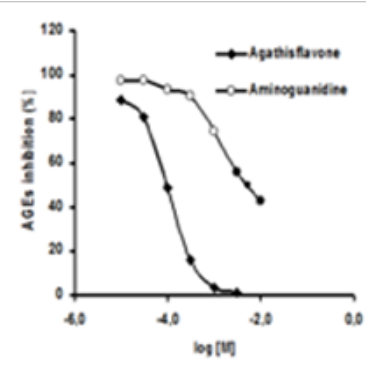

(B)
Figure 3 A Inhibitory effect of $A$. occidentale extracts on fluorescence intensity of glycated BSA in terms of \% AGEs inhibition. (B) Inhibitory effect of Agathisflavone on fluorescence intensity of glycated BSA in terms of \% AGEs inhibition.

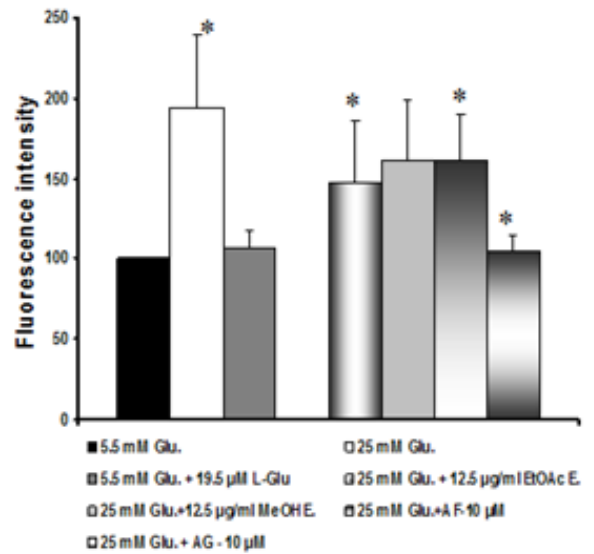

Figure 4 Fluorescence of advanced glycosylation end-products (AGEs) in EAhy 926 cells cultured in physiological or high glucose concentrations, supplemented with A. occidentale leaves extracts or an isolated biflavonoid. Glu, D-Glucose; L, Glu; L, glucose;AF, Agathisflavone; AG, Aminoguanidine

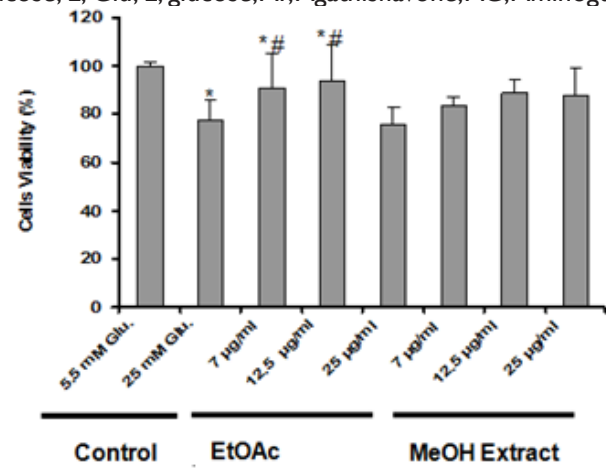

Figure 5 Effect of $A$. occidentale leaves extracts on high glucose-induced loss of cell viability. Eahy cells were cotreated with the indicated concentrations of A. occidentale and high glucose $(25 \mathrm{mmol} / \mathrm{l})$ for 7 days.
(A)

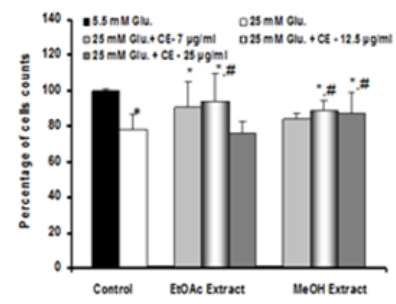

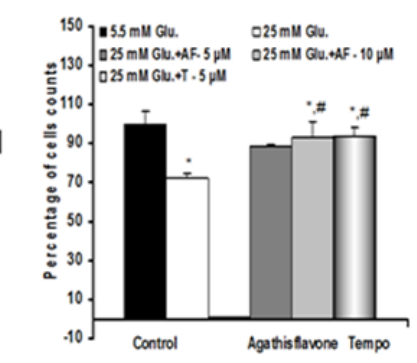

(B)
Figure 6 Proliferation of endothelial cells cultured in 5.5 or $25 \mathrm{mmol} / /$ glucose, A.occidentale leaves extract (A) or isolated compound (B).

Effect of Anacardium occidentale leaf extracts or an isolated bi flavonoid (Agathisflavone) on high glucose-induced loss of EAhy 926 cells viability. Cytotoxicity assay based on MTT revealed that none of the extracts of plant or identified compound at the doses tested was toxic to the EA.hy 926 endothelial cells after 7days exposure (data not shown).

\section{Total cells lysate nitrates/nitrites}

As shown in Figure 7, exposure of endothelial cells to hyperglycaemic $(25 \mathrm{mM})$ conditions for 7 days caused a significant $(p<0.05)$ increase of the level of total nitrates/nitrites in cell lysate compared to normoglycemic control group (13.17 \pm 0.46 vs $4.95 \pm 0.46 \mu \mathrm{mol} / \mathrm{ml})$. Co-treatment of hyperglycaemic-exposed cells with $A$. occidentale leaf ethyl acetate extract (E3) or methanol extract (E4) for 7days significantly $(\mathrm{p}<0.05)$ reduced the total level of nitrates/nitrites compared with the hyperglycemic group by $27.7 \%$ and $33.1 \%$ respectively. When L-glucose $(19.5 \mathrm{mM})$ was used as osmotic control, EA.hy cells did not show any increase in total nitrate/nitrite. The $15 \%$ and 21 reduction of total nitrates/nitrites respectively with agathisflavone (identified compound) and non-identified compound (Q13) was not significant while tempol failed to reduce the total level of nitrate/nitrite in cell lysate (Figure 7).

Effects of EtOAc and $\mathrm{MeOH}$ extracts and their major compounds on hyperglycaemia induced on NF-kB, Mn-SOD and catalase expressions. A. occidentale leaf extracts and identified compounds at different concentrations, maintained in DMEM containing 5.5 or $25 \mathrm{mM}$ glucose for 7 days, were harvested and NF-kB, Mn-SOD and catalase expression were measured.

High glucose treatment $(25 \mathrm{mM})$ but not $19.5 \mathrm{mM}$ L-Glucose markedly increased expression of NF-kB (125\%) (Figure 8). E3 or Q13 cotreatement with HG, largely prevented NF-kB expression and it expression was 98 and $101 \%$ respectively.

High glucose treatment markedly enhanced EA.hy 926 endothelial cells' Catalase expression (by 1.37 fold) compared to normal glucose. HG effect on catalase expression was not attenuated by either Cashew's extracts (E3 and E4) or compounds isolated from these extracts.

MnSOD protein expression and activity were determined in EA. Hy926 cells cultured in high and normal glucose concentrations to determine whether hyperglycemia affects this enzyme and cellular defense mechanism against oxidative stress. Following 7days exposure to HG, the mitochondrial superoxide generation (MnSOD) were significantly elevated in comparison to the NG incubations (Figure 8). All treatment with plant extracts and compounds for 7 days significantly attenuated the HG-induced superoxide generation. 


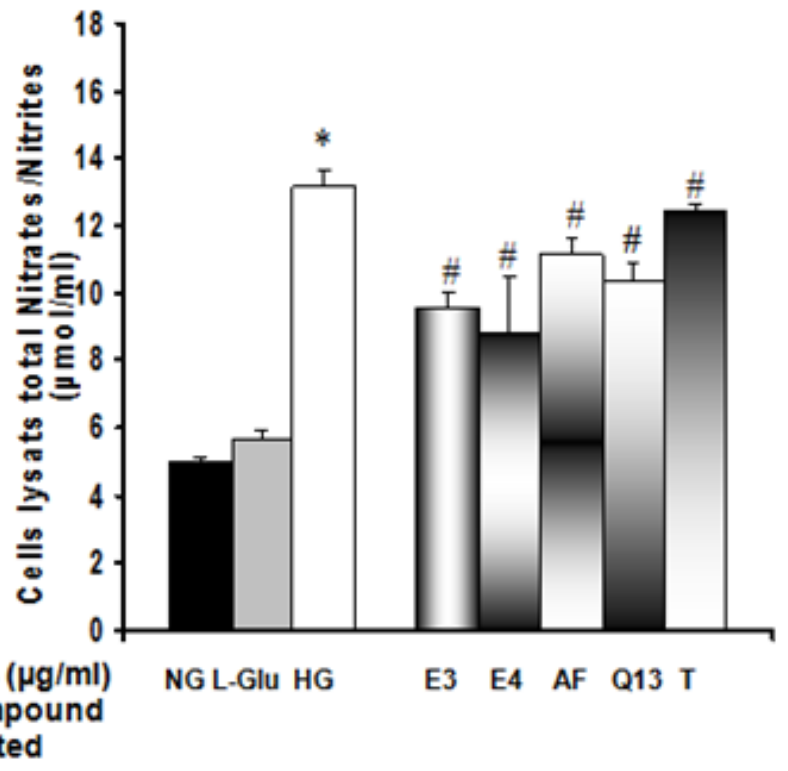

Figure 7 Effect of glucose on total cells lysate nitrates/nitrites.

NG, Normoglycemic, $5.5 \mathrm{mmol} / /$ glucose; HG, Hyperglycemic, $25 \mathrm{mmol} / /$ glucose; control, NG+19.5mmol// L-glucose (osmotic control). The levels of nitrate/ nitrite cultured in NG, HG, control medium or diffent treatments (E3, A.occidentale leaves ethyl acetae extract, $12 \mu \mathrm{g} / \mathrm{ml}$; E4, A.occidentale methanol extract, I2 $\mu \mathrm{g} /$

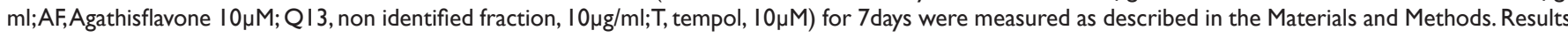
are expressed as mean $\pm \mathrm{SE}$ from three separate experiments.

$*_{\mathrm{p}}<0.05$ difference compared to NG group and ${ }_{\mathrm{p}}<0.05$ difference compared to HG group.

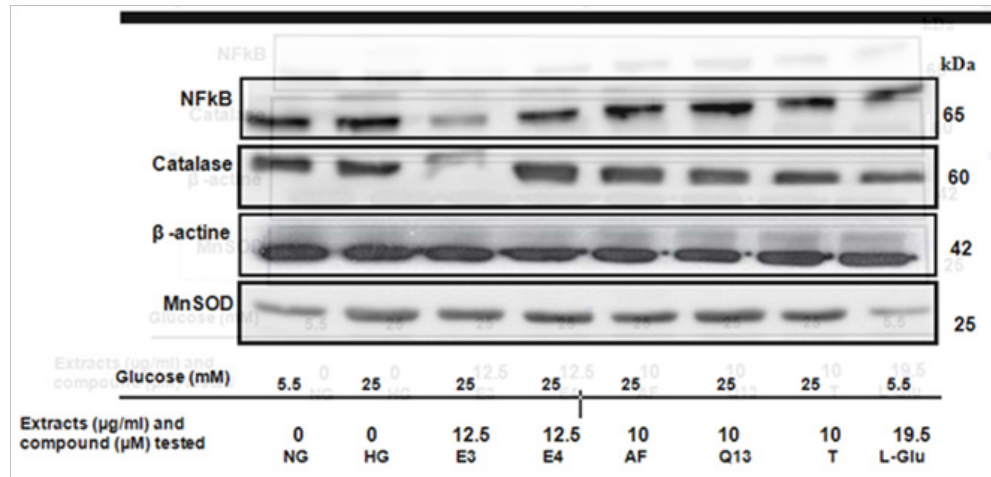

(A)

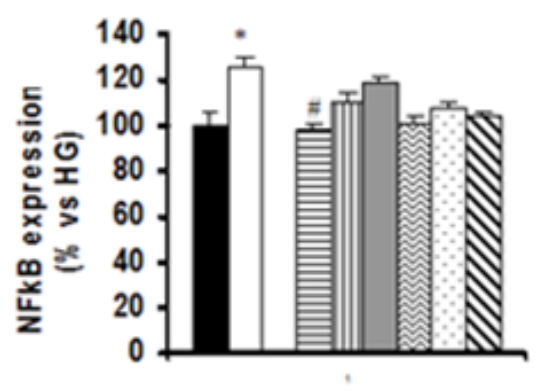

(B1)

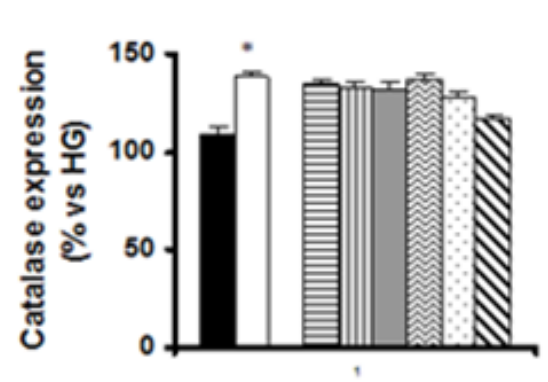

(B2)

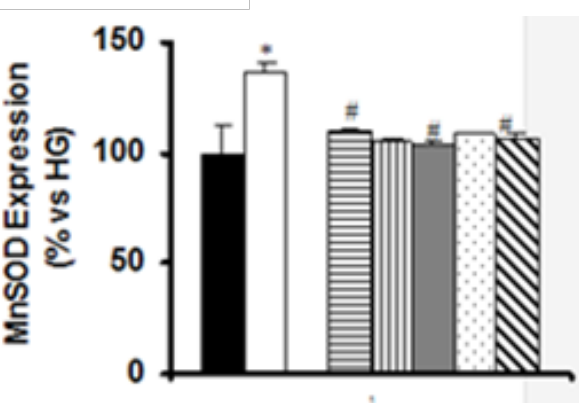

(B3)

Figure 8 A Representative Western blots showing the protein expression of NFkB, catalase and Mn-superoxide dismutase (SOD) in EAhy endothelial cells cultured under NG, normoglycaemic (lanes I; $5.5 \mathrm{mmol} / \mathrm{l})$ and HG, hyperglycaemic $(25 \mathrm{mmol} / /$ glucose) conditions, L-Glu, control medium (NG+19.5mmol// L-glucose) or different treatments (HG+E3, A.occidentale leaves ethyl acetae extract, $12 \mu \mathrm{g} / \mathrm{ml}$ or $+\mathrm{E} 4$, A.occidentale methanol extract, $12 \mu \mathrm{g} / \mathrm{ml}$ or AF,Agathisflavone

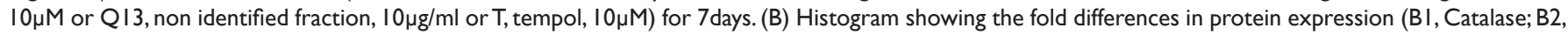
NF-kB; B3, Mn-SOD) observed in EAhy cultured under hyperglycaemic vs normoglycaemic conditions or vs different treatments. 


\section{Discussion}

Anacardium occidentale Linn (A. occidentale) is commonly cultivated for its edible fruits and nut which have high medicinal value particularly on diabetic and hypertension diseases. Diabetic state has been shown to enhance oxidative stress, however, very little is known in regards of $A$. occidentale antioxidant impact on this metabolic disease. In attempting to correct this, in the present study we demonstrated that extracts of A. occidenatle leaves possess antioxidant properties In addition, one identified compound (Agathisflavone) and one unidentified compound (Q13) isolated from these extracts showed similar properties.

Assays such as the scavenging of DPPH and anti-glycation by cyclohexane (E1), dichloromethane (E2), ethyl acetate (E3) and methanol (E4) extracts of $A$. occidentale leaves plus an identified compound (Agathisflavone) and an unidentified compound (Q13) isolated from these extracts were performed. Our data clearly established that E3 and E4 extracts of A. occidentale possessed significant DPPH radical-scavenging activity with Trolox equivalence values of $218 \pm 8$ and $760 \pm 3 \mathrm{mg}$ trolox/dried extract, respectively, and the DPPH scavenging value of E3 and E4 was sigfnificantly stronger than that of standard antioxidant, Romarin $(64 \pm 7 \mathrm{mg}$ trolox/ dried extract). Our results imply that there are abundant antioxidative phytochemicals present in the acetate and methanol extracts of $A$. occidentale leaves. This was confirmed by testing the scavenging of DPPH by Q13, a non-identified compound isolated from E3, which compared well to chlorogenic acid as standard $(642 \pm 3$ vs $53 \pm 2 \mathrm{mg}$ trolox/dried extract).

In this study, synthetic DPPH was utilized to assess radical scavenging abilities of $A$. occidentale extracts in order to identify the potent extract among E1, E2, E3 and E4.This method is widely used for the determination of the radical scavenging abilities of plants. Although these radicals may not be biologically relevant, they provide an indication of hydrogen/electron-donating capacity of plants and are hence a useful measure of in vitro antioxidant activity.

Previous phytochemical and pharmacological investigations of $A$. occidentale leaves have shown the presence of myricetin, agathisflavone, robustaflavone, amentoflavone, quercetin, kaempferol, apigenin, quercetin 3-O-rhamnoside, and quercetin 3-O-glucoside. The biological properties of flavonoids have been focused on extensively because they are natural antioxidant products with little cytotoxicity. They have also been recognized to possess anti-inflammatory, antiviral and anti-carcinogenic antidiabetic and anti-hypertensive activities (Fujii et al., 2006). Flavonoids can exhibit their antioxidant activity in several ways: (i) radical scavenging activity (ii) prevention of the transition metal-catalyzed production of reactive species (iii) interaction with other antioxidants (such as cooperative actions), localization, and mobility of antioxidant at the microenvironment. ${ }^{16}$

Since $A$. occidentale extracts were potent on the radical scavenging abilities, we hypothesized that crude extracts with powerful antioxidant properties may inhibit Advanced Glycation End products (AGEs). To determine any link between antioxidant activity of $A$. occidentale leaf extracts and glycation and oxidation, we evaluated antiglycation activity of the 4 different extractions of $A$. occidentale's leaves in vitro. Of the 4 extracts tested, the EtOAc fraction (E3) exhibited the strongest inhibitory activity against AGEs formation in the BSA-ribose assay, and its IC50 value $(0.070 \mathrm{mg} / \mathrm{ml})$ was less than one tenth that of aminoguanidine as standard $(0.826 \mathrm{mg} / \mathrm{ml})$ (Table 1). This anti-AGEs effect could be explained by the presence of Agathisflavone, the biflavonoid extracted and identified from the EtOAc (E3) extraction which exhibited a significant inhibitory effect on AGEs formation compared to the E3 crude extract. This effect was more potent than that of aminoguanidine as a standard. Our results also demonstrated that protein glycation and oxidation could be inhibited effectively when flavonoids were added during the glycoxidative process in endothelial cells. AGEs breakers may help to provide a protective effect against hyperglycaemia-mediated protein damage and subsequently improve the pathophysiology of diabetes and its complications. ${ }^{17}$

In the second set of our study, we used endothelial cells to characterize metabolic disturbances that occur following chronic exposure to high levels of glucose. We then appreciated the abilities of the EtOAc and $\mathrm{MeOH}$ extracts and the principle identified compound to protect endothelial cells against high glucose and AGE-induced cellular toxicity. To demonstrate glucose induced inhibition of cell proliferation in vitro we used EA.hy 926 endothelial cells which have been recognized to have higher sensitivity to oxLDL-induced injury associated with weaker enzymatic antioxidant defences. ${ }^{18}$ Circulating concentrations of glucose can range from around $10 \mathrm{mmol} / 1$ to $>50 \mathrm{mmol} / 1$ in severely untreated diabetic patients. For an in vitro model system of vascular endothelial cells, we chose glucose concentrations from $5.5-25 \mathrm{mmol} / 1$ to represent a range corresponding to normal and diabetic conditions. The normal growth medium was supplemented with an additional $25 \mathrm{mmol} / 1$ for the majority of experiments as this concentration induced a reduction of proliferation activity of endothelial cells. This concentration is similar to that used in other similar studies investigating the effects of glucose on protein glycation and oxidative stress in macrovessel and microvessel endothelial cells. ${ }^{19}$ In our study, E3 and E4 were both effective in protecting cells against glucose- and AGE-mediated toxicity except $25 \mu \mathrm{g} / \mathrm{ml}$ of E3. On the other hand, coincubation of identified compound agathisflavone with high glucose for 7 days showed proliferation of endothelial cells (93\%) higher than that of cells grown in high glucose alone (71\%). In agreement with other studies, it has been demonstrated that our isolated and identified biflavonoid, Agathisflavone, also increased cell survival and RA-induced neuronal differentiation in pluripotent stem cells. ${ }^{20}$ The flavonoid isolated from $A$. occidentale leaf extracts, namely Agathisflavone, should be added to the list of other 10 flavonoids isolated from P. linteus which have been shown by Lee et al. ${ }^{21}$ to protect cultured endothelial cells following exposure to bovine serum albumin derived advanced glycation endproducts.

It could thus be of great health benefit to propose that administrations of naturally occurring flavonoids are beneficial for the prevention of protein glycation in high glucose environments such as diabetes. Our data on Agathisflavone's anti-glycation activities is in agreement of those of Manual et al., ${ }^{22}$ who demonstrated that daflon 500, a clinical drug which is made up of flavonoids, had attenuated effect on $\mathrm{HbA1C}$ and protein glycation in a group of twenty eight Type 1 diabetic patients. This probably indicates that the $A$. occidentale extracts can either scavenge hydroxyl radicals as justified by the reduction of the total nitrate/nitrite observed after cotreatment of endothelial cells with high glucose and different treatment (E3, E4, Agatiflavone, Q13 and Tempol); the crude extracts could also act by chelating transition metals leading to less hydroxyl radical production, or they may have both effects. Increasing evidence suggests that glucose and AGEs, at 
concentrations reflecting those found in the plasma of diabetic patients, exerts profound effects on vascular function, secondary to inhibition of endothelial cell NO generation. ${ }^{23}$ Natural compounds, such as agathisflavone tested in our study, which have combined anti-glycation and antioxidant properties are likely to offer maximum therapeutic potential. The effect of high glucose levels on cellular metabolism and cell growth is likely to be mediated by intracellular signaling. We have founded in the current study that exposure endothelial cells culture to $A$. occidentale for 7 days elicits significant increases in nuclear factor kB (NF-kB), Manganese Superoxide Dismutase (MnSOD) and Catalase expression. What is the link between all these components and diabetes? In diabetes, NF-kB is an oxidant-sensitive transcription factor, and hyperglycemia induced oxidative stress may play a key role in the pathogenesis of diabetic vascular disease. In this study, we demonstrated that prolonged hyperglycemia can lead to the formation of AGEs which could act through specific receptors on vascular cells to directly activate NF-kB. The nuclear factor $\mathrm{kB}$ in vascular smooth muscle cells can induce pathological changes in gene expression found in atherosclerosis and diabetic ${ }^{24}$ complications. Removal of toxic oxygen metabolites is the putative function of antioxidant enzymes such as CuZnSOD, MnSOD, GPX and Catalase. To test whether E3 and E4 extracts and identified compound, Agathisflavone, impact the cell viability exposed endothelial cells to high glucose to mimic diabetic conditions.

Co-incubation of EAhy cells with E3 and E4 caused a significant decrease in the NF-kB and Mn-SOD expression in cells treated with high glucose. Agathisflavone, the identified compound, failed to alter proteins expression but the non-identified compound, namely Q13, significantly decreased NF-kB Catalase and MnSOD expression in cells treated with high glucose $(\mathrm{P}<0.05$ vs High Glucose). The reduction of the NF-kB expression by these cashew leaf extracts could be explained by the presence of Q13 (non- identified compound) in our extracts or other compounds such as anacardic acid which has been shown to suppresses expression of NF- $\mathrm{KB}$-regulated gene products in cancer cells (Sun et al., 2006). Glucose autoxidation products can attach to specific receptors from the surface of endothelial cells and change their properties, contributing to early formation of atherosclerotic lesions. ${ }^{25}$ Among the pathways studied, MnSOD appears to play the most crucial role in diabetic complications. In this study, we observed that MnSOD was not altered after EA.hy endothelial cells were expose to high glucose and different extracts (E3 and E4). MnSOD is an enzyme stimulating conversion of superoxide to hydrogen peroxide $(\mathrm{H} 2 \mathrm{O} 2)$ and previous studies have suggested that $\mathrm{H}_{2} \mathrm{O}_{2}$ plays a central role in NF-kB activation in coronary artery endothelial cells. Hyperglycemia-induced superoxide generation might also favour increased expression of iNOS through the activation of NF-kB, which increases the generation of nitric oxide (NO) ${ }^{26}$ It therefore appears reasonable to hypothesize that elevated expression and activity of antioxidant enzymes is an adaptive response of endothelial cells to meet the biological demand exerted by hyperglycaemic-induced oxidative stress..$^{27-32}$

\section{Conclusion}

Collectively, we have made novel observations in our present experiment. First, the $\mathrm{MeOH}$ extract of $A$. occidentale leaves is the most potent in scavenging the DPPH. Second, we found out that the EtOAc extract of $A$. occidentale leaves possesses strong glycation activities and the free radical scavenging of its isolated compound, Agathisflavone may contributes in part to their antiglycation effects.
The extracts of A.occidentale leaves and the principal compound identified also protect endothelial cells against glucose toxicity by attenuating High Glucose-induced MnSOD and NF-kB generation. In this regard, EtOAc and/or $\mathrm{MeOH}$ extract of $A$. occidentale leaves may protect endothelial cells against free radical-induce cell damage in diabetes complications.

\section{Acknowledgments}

This study was facilitated by the Grants commission of Association of Francophone Universities, Cameroon which provided us the postdoctoral fellowship for scientific research $\left(\mathrm{N}^{\circ} 1001 \mathrm{PP} / 224 /\right.$ BAC 2008). Authors gratefully acknowledge the Department of Integrated Neurovascular Biology (UMR CNRS 6214-INSERM 771) of University of Angers, France, for research support and material to carry out this project.

\section{Conflits of interest}

Author déclares no conflicts of interest.

\section{References}

1. Tedong L, Dimo T, Dzeufiet DPD, et al. Antihyperglycemic and renal protective activities of Anacardium occidentale (Anacardiaceae) leaves in Streptozotocin induced diabetic rats. Afr $J$ Traditional, Complementory and alternative Medicines. 2006;3(1):23-35.

2. Tedong L, Dimo T, Dzeufiet DPD, et al. Effect of leaf Anacardium occidentale L. (Anacardiaceae) hexane extract on reproductive function in streptozotocin-induced diabetic rats. Phototherapie. 2007;5:182193.

3. Tedong L, Padma M, Martineau LC, et al. Hydro-ethanolic extract of cashew tree (Anacardium occidentale) nut and its principal compound, anacardic acid, stimulate glucose uptake in $\mathrm{C} 2 \mathrm{C} 12$ muscle cells. Mol Nutr Food Res. 2010;54(12):1753-1762.

4. International Diabetes Federation (IDF). $4^{\text {th }}$ edn. IDF Atlas; 2009. p. 7.

5. Buse JB, Rosenstock J, Sesti G, et al. Liraglutide once a day versus exenatide twice a day for type 2 diabetes:a 26-week randomised, parallel-group, multinational, open-label trial (LEAD-6). Lancet; 2009;374(9683):39-47.

6. Curcio F, Ceriello A. Decreased cultured endothelial cell proliferation in high glucose medium is reversed by antioxidants:new insights on the pathophysiological mechanisms of diabetic vascular complications. In Vitro Cell Dev Biol. 1992;28(11-12):787-790.

7. Song $\mathrm{P}, \mathrm{Wu} \mathrm{Y}, \mathrm{Xu}$ J, et al. Reactive Nitrogen species by hyperglycemia suppress Akt signalling and triggers apoptosis by upregulating phosphatise PTN (Phosphatase and tensin homologue deleted on chromosome 10) inan LKB1-Dependant manner. Circulation. 2007;116(14):1585-1595.

8. Marchetti Piero, Matthews David. Pancreatic $\beta$-cell in type 2 diabetes. Birth, life, failure and rescue. $1^{\text {st }}$ edn. Oxford, UK: Ed Wiley-Blackwell; 2009. p 75-113.

9. Williams-Herman D, Johnson J, Teng R, et al. Efficacy and safty on combinaison therapy with sitagliptin and metformin in patients with type 2 diabetes:a 54-week study. Cur Med Res Opi. 2009;25(3):569583.

10. Konan NA, Bacchi EM. Antiulcerogenic effect and acute toxicity of hydroethanolic extract from the cashew (Anacardium occidentale L.) leaves. J Ethnopharmacol. 2007;112(2):237-242.

11. Kamath V, Rajini PS. The efficacy of cashew nut (Anacardium occidentale L.) skin extract as free radical scanvenger. Food Chemistry. 2007;103(1):428-433. 
12. Melo-Cavalcante AA, Picada J N, Rubensam G, et al. Antimutagenic activity of cashew apple (Anacardium occidentale Sapindales, Anacardiaceae) fresh juice and processed juice (cajuína) against methyl methanesulfonate, 4-nitroquinoline $\mathrm{N}$-oxide and benzo[a] pyrene. Genet Mol Biol. 2008;31(3):751-766.

13. Sokeng DS, Kamtchouing P, Watcho P, et al. Hypoglycémic activity of Anacardium occidentale L. Aqueous extract in normal and streptozotocin-induced diabetic rats. Diab Res. 2008;36:001-009.

14. Ojewole JA. Laboratory evaluation of hypoglycemic effect of Anacardium occidentale Linn (Anacardiaceae) stem-bark extracts in rats. Methods Find Exp Clin Pharmacol. 2003;25(3):199-204.

15. Gondwe M, Kamadyaapa DR, Tufts $M$, et al. Sclerocarya birrea [(A. Rich.) Hochst.] [Anacardiaceae] stem-bark ethanolic extract (SBE) modulates blood glucose, glomerular filtration rate (GFR) and mean arterial blood pressure (MAP) of STZ-induced diabetic rats. Phytomedicine. 2008;15(9):699-709.

16. Apak R, Güçü K, Demirata B, et al. Comparative evaluation of various total antioxidant capacity assays applied to phenolic compounds with the CUPRAC assay. Molecules. 2007;12(7):1496-1547.

17. Ardestani A, Yazdanparast R. Inhibitory effects of ethyl acetate extract of Teucrium polium on in vitro protein glycoxidation. Food Chem Toxicology. 2007;45(12):2402-2411.

18. Claise C, Chalas J, Edeas M, et al. Comparison of oxidized lowdensity lipoprotein toxicity on EA.hy 926 cells and human vein endothelial cells:influence of antioxidant systems. Cell Mol Life Sci. 1997;53(2):156-161.

19. Padayatti PS, Jiang C, Glomb MA, et al. A high concentration of glucose induces synthesis of argpyrimidine in retinal endothelial cells. Curr Eye Res. 2011;23(2):106-115.

20. Paulsen BS, Souza CS, Chicaybam L, et al. Agathisflavone enhances retinoic acid-induced neurogenesis and its receptors $\alpha$ and $\beta$ in pluripotent stem cells. Stem Cells Dev. 2011;20(10):1711-1721.

21. Lee YS, Kang YH, Jung JY, et al. Protein Glycation Inhibitors from the Fruiting Body of Phellinus linteus. Biol Pharm Bull. 2008;31(10):19681972.
22. Manuel y Keenoy B, Vertommen J, De Leeuw I. The effect of flavonoid treatment on the glycation and antioxidant status in Type 1 diabetic patients. Diabetes Nutr Metab. 1999;12(4):256-263.

23. Xu B, Chibber R, Ruggerio D, et al. Impairment of vascular endothelial nitric oxide synthase activity by advanced glycation end products. FASEB. 2003;17(10):1289-1291.

24. Sung B, Pandey MK, Ahn KS, et al. Anacardic acid (6-Nonadecyl Salicylic Acid), an inhibitor of histone acetyltransferase, suppresses expression of $\mathrm{NF}-\kappa \mathrm{B}$-regulated gene products involved in cell survival, proliferation, invasion and inflammation through inhibition of $\mathrm{I} \kappa \mathrm{B} \alpha$ kinase, leading to potentiation of apoptosis. Blood. 2008;111(10):4880 4891.

25. Goycheva P, Gadjeva V, Popov B. Oxidative stress and its complications in diabetes mellitus. Trakia Journal of Sciences. 2006;4(1):1-8.

26. Pacher P, Beckman J, Liaudet L. Nitric oxide and peroxynitrite in health and disease. Physiol Rev. 2007;87(1):315-424.

27. Cracowski JL, Devillier P, Durand T, et al. Vascular biology of the isoprostanes. J Vasc Res. 2001;38(2):93-103.

28. Dogne JM, Hanson J, Domenico P. Thromboxane, prostacyclin and isoprostanes:therapeutic targets in artherogenesis. Trends Pharmacol Sci. 2005;26(12):639-644.

29. Fujii H, Yokozawa T, Kim YA, et al. Protective effect of grape seed polyphenols against high glucose-induced oxidative stress. Biosci Biotechnol Biochem. 2006;70(9):2104-2111.

30. Kubo I, Muroi H, Himejima M, et al. Structure-antibacterial activity relations of anacardic acids. J Agric Food Chem. 1993;41(6):10161019.

31. Li SP, Zhang GH, Zeng Q, et al. Hypoglycemic activity of polysaccharide, with antioxidation, isolated from cultured Cordyceps mycelia. Phytomedicine. 2006;13(6):428-433.

32. Morrow JD. Quantification of isoprostanes as indices of oxidant stress and the risk of atherosclerosis in humans. Arterioscler Thromb Vasc Biol. 2005;25(2):279-286. 